\title{
College Counselors' Performance Measure System and Fuzzy Measure Analysis Model
}

\author{
http://dx.doi.org/10.3991/ijet.v10i8.5282 \\ Xin Xia, Guolei Zhang \\ Agricultural University of Hebei, Baoding, Hebei, China
}

\begin{abstract}
We evaluate the performance of college counselors so as to find ways to promote competence of college counselors as well as teaching quality and core competence of the colleges. The issue of performance measure analysis is discussed and a performance measure system is devised. The indicators are selected based on the multi-perspective and multi-level principle, thus enhancing the reasonability, validity and operability of the measure system. A modified fuzzy measure analysis model is established, and a qualitative approach is combined with a quantitative approach for the fuzzy analysis of various indicators. The membership model is built for fuzzy measure of the performance of college counselors, and the best counselors are found out based on fuzzy membership. Finally, the propose model is verified through a specific case.
\end{abstract}

Index Terms-Colleges and universities, counselor, performance, measure system and model, fuzzy theory, gray system theory

\section{INTRODUCTION}

Counselors are important part of the teaching team in colleges and universities. Besides teaching, they also bear the responsibility of student administration. The performance of college counselors directly affects the competence and scientific development of colleges and universities ${ }^{[1-3]}$. The topic of performance evaluation of college counselors is highlighted after the issuance of Regulations on Constructing the Team of College Counselors and Opinions on Enhancing the Construction of the Team of College Counselors ${ }^{[4-5]}$. Some constructive progress has been achieved in performance evaluation of college counselors ${ }^{[6-9]}$, but several limitations are summed up: (1) The selection of performance evaluation indicators lacks scientificity, normativity and objectivity; (2) The quantitative model for performance measure analysis of college counselors is not fully formalized, leading to large deviation of the performance evaluation results; (3) The fuzzy indicators are usually measured by specific values, so fuzzy analysis is not realized in real sense. The reliability of the performance measure analysis of college counselors remains to be improved. In this study, we aim to investigate the college counselors' performance measure system through survey and statistics and establish a modified performance measure system. A fuzzy measure model for performance evaluation is proposed by using the gray system theory ${ }^{[10-12]}$ and fuzzy theory ${ }^{[13-15]}$. This model provides a new pathway for performance evaluation of college counselors.

\section{MODIFIED COLLEGE COUNSELORS' PERFORMANCE MEASURE SYSTEM}

A scientific performance measure system is the precondition for college counselors' performance evaluation. The performance measure should be implemented jointly by experts, college leaders, teachers and students. Moreover, the selection of measure indicators should be based on the multi-level and multi-perspective principle. Here we construct a modified performance measure system by clustering analysis after soliciting opinions, statistical analysis, questionnaire survey and referring to the performance evaluation system and standards of colleges and universities. This measure system consists of indicators in five aspects, namely, caucus construction, employment guidance, daily affairs handling, professional qualification and occupational quality. The indicators selected for each aspect are shown in Table 1.

\section{FUZZY MEASURE MODEL FOR PERFORMANCE EVALUATION OF COLLEGE COUNSELORS}

\section{A. Scheme set and indicator set for performance measure analysis}

Suppose $m$ college counselors are evaluated and the set $P$ of performance measure analysis schemes is formed:

$$
P=\left(P_{1}, P_{2}, \mathrm{~L}, P_{m}\right)
$$

The above measure indicators constitute the primary indicator set $C$ and the secondary indicator set $C_{i}$, i.e.

$$
\begin{aligned}
& C=\left(C_{1}, C_{2}, C_{3}, C_{4}, C_{5}\right) \\
& C_{i}=\left(c_{i 1}, c_{i 2}, \mathrm{~L}, c_{i m_{i}}\right), 1 \leq i \leq 5
\end{aligned}
$$

Where $m_{i}$ is the number of secondary indicators in set $C_{i}$

Thus for $m$ counselors, the performance measure analysis $A_{m x n}$ is obtained for the performance evaluation scheme set based on the above indicators:

(4)

$$
A_{m x n}=\left[\begin{array}{cccc}
a_{11} & a_{12} & \mathrm{~K} & a_{1 n} \\
a_{21} & a_{22} & \mathrm{~L} & a_{2 n} \\
\mathrm{M} & \mathrm{M} & \mathrm{L} & \mathrm{M} \\
a_{m 1} & a_{m 2} & \mathrm{~L} & a_{m n}
\end{array}\right]
$$

Where $a_{i j}$ is the value of measure indicator $j$ for counselor $i$. 
PAPER

College Counselors’ Performance Measure System and Fuzzy Measure Analysis Model

TABLE I.

COLLEGE COUNSELORS' PERFORMANCE MEASURE SYSTEM

\begin{tabular}{|c|c|c|}
\hline Primary indicator & Secondary indicator & Description \\
\hline \multirow{5}{*}{ Caucus construction $C_{1}$} & $\begin{array}{l}\text { Party and league member administration capacity } \\
\mathcal{C}_{11}\end{array}$ & \multirow{5}{*}{$\begin{array}{l}\text { This indicator deals with the counselor's ability in } \\
\text { implementing caucus construction and cultivating } \\
\text { applicants for party membership. Improving the quality } \\
\text { of caucus construction is the basic responsibility of } \\
\text { counselors in ideological and political aspect }\end{array}$} \\
\hline & $\begin{array}{l}\text { Cultivation of applicants for party membership } \\
C_{12}\end{array}$ & \\
\hline & Ideological and political education $C_{13}$ & \\
\hline & Ability in organization party branch activities $\mathcal{C}_{14}$ & \\
\hline & Social services and practice $\mathcal{C}_{15}$ & \\
\hline \multirow{6}{*}{ Employment guidance capacity $C_{2}$} & Career planning for students $\mathcal{C}_{21}$ & \multirow{6}{*}{$\begin{array}{l}\text { This indicator reflects counselor's ability and attitude } \\
\text { in providing guidance for students' employment. A } \\
\text { major responsibility of the counselor is to provide } \\
\text { effective assistance in student employment and career } \\
\text { planning. }\end{array}$} \\
\hline & $\begin{array}{l}\text { Validity of employment information published } \\
c_{22}\end{array}$ & \\
\hline & $\begin{array}{l}\text { Ability in organization employment recruitment } \\
\text { conference } c_{23}\end{array}$ & \\
\hline & Employment rate $\mathcal{C}_{24}$ & \\
\hline & Cultivation of students' employment ability $\mathcal{C}_{25}$ & \\
\hline & Cultivation of students' professional ethics $\mathcal{C}_{26}$ & \\
\hline \multirow{8}{*}{ Daily affairs handling capacity $C_{3}$} & Construction of student organizations $\mathcal{C}_{31}$ & \multirow{8}{*}{$\begin{array}{l}\text { This indicator reflects counselor's ability in supervis- } \\
\text { ing students' daily life and learning activities. To } \\
\text { effectively deal with emergency, ensure students' } \\
\text { safety, organize diversified scientific activities and } \\
\text { enhance the construction of academic atmosphere and } \\
\text { examination discipline are the basic responsibilities of } \\
\text { the counselors. }\end{array}$} \\
\hline & $\begin{array}{l}\text { Construction of academic atmosphere and exami- } \\
\text { nation discipline } \mathcal{C}_{32}\end{array}$ & \\
\hline & Administration of students' learning and life $\mathcal{C}_{33}$ & \\
\hline & $\begin{array}{l}\text { Safeguard of students' ability and psychological } \\
\text { guidance } \mathcal{C}_{34}\end{array}$ & \\
\hline & Response to emergency events $\mathcal{C}_{35}$ & \\
\hline & $\begin{array}{l}\text { Ability in organizing extracurricular activities } \\
\boldsymbol{C}_{36}\end{array}$ & \\
\hline & Student administration $\mathcal{C}_{37}$ & \\
\hline & Reward and punishment mechanism $\mathcal{C}_{38}$ & \\
\hline \multirow{8}{*}{ Professional qualification $C_{4}$} & Educational and teaching methodology $\mathcal{C}_{41}$ & \multirow{8}{*}{$\begin{array}{l}\text { This indicator is concerned with the professional } \\
\text { qualification of the counselors. Professional qualifica- } \\
\text { tion of the counselors is the premise for the cultivation } \\
\text { of qualified graduates. }\end{array}$} \\
\hline & Educational and teaching innovation $\boldsymbol{C}_{42}$ & \\
\hline & Scientificity of education and teaching $c_{43}$ & \\
\hline & Qualification ratio of student cultivation $\mathcal{C}_{44}$ & \\
\hline & $\begin{array}{l}\text { Standard-reaching rate of scientific research pro- } \\
\text { grams } \mathcal{C}_{45}\end{array}$ & \\
\hline & Standard-reaching rate of academic papers $C_{46}$ & \\
\hline & Proportion of problem students $C_{47}$ & \\
\hline & Specialized knowledge $c_{48}$ & \\
\hline Occupational quality $C_{5}$ & Sense of responsibility $C_{51}$ & $\begin{array}{l}\text { This indicator measures other occupational qualifies } \\
\text { that a counselor is supposed to possess. Higher occupa- } \\
\text { tional quality of the counselors can help them fulfill } \\
\text { their responsibilities more effectively. }\end{array}$ \\
\hline
\end{tabular}




\section{B. Normalization of different types of measure indicators}

Different measure indicators may have different dimensionality. The fuzzy indicators are usually expressed by intervals. Therefore, the measure indicators are first normalized.

The fuzzy indicators are scored using hundred-mark system. The fuzzy indicators and their meanings are shown in Table II.

TABLE II.

NORMALIZATION OF FUZZY INDICATORS

\begin{tabular}{|c|c|l|l|}
\hline \multicolumn{2}{|c|}{ Indicator } & \multicolumn{2}{c|}{ Meaning } \\
\hline $\begin{array}{l}\text { Positive } \\
\text { indicator }\end{array}$ & $\begin{array}{l}\text { Negative } \\
\text { indicator }\end{array}$ & Positive indicator & Negative indicator \\
\hline 100 & 0 & Best & Worst \\
\hline 90 & 10 & Very good & Very poor \\
\hline 70 & 30 & Good & Poor \\
\hline 50 & 50 & Moderate & Moderate \\
\hline 30 & 70 & Poor & Good \\
\hline 10 & 90 & Very poor & Very good \\
\hline 0 & 100 & Worst & Best \\
\hline \multicolumn{2}{|c|}{$20,40,60,80$} & $\begin{array}{l}\text { Intermediate be- } \\
\text { tween two adjacent } \\
\text { states }\end{array}$ & $\begin{array}{l}\text { Intermediate be- } \\
\text { tween two states }\end{array}$ \\
\hline
\end{tabular}

Let the initial value of measure indicator $j$ for counselor $i$ is $r_{i j}=\left[r_{i j}^{l e f}, r_{i j}^{r i g}\right]$, then the value after normalization is $v_{i j}=\left[v_{i j}^{l e f}, v_{i j}^{r i g}\right]$.

The formula for the normalization of cost-related measure indicator $j$ is

$$
\begin{aligned}
v_{i j}^{l e f} & =\frac{\max _{1 \leq i \leq m}\left(v_{i j}^{r i g}\right)-r_{i j}^{r i g}}{\max _{1 \leq i \leq m}\left(v_{i j}^{r i g}\right)-\min _{1 \leq i \leq m}\left(r_{i j}^{l e f}\right)} \\
v_{i j}^{r i g} & =\frac{\max _{1 \leq i \leq m}\left(v_{i j}^{r i g}\right)-r_{i j}^{l e f}}{\max _{1 \leq i \leq m}\left(v_{i j}^{r i g}\right)-\min _{1 \leq i \leq m}\left(r_{i j}^{l e f}\right)}
\end{aligned}
$$

The formula for the normalization of benefit-related measure indicator $j$ is

$$
\begin{aligned}
v_{i j}^{l e f} & =\frac{r_{i j}^{l e f}-\min _{1 \leq i \leq m}\left(r_{i j}^{l e f}\right)}{\max _{1 \leq i \leq m}\left(v_{i j}^{r i g}\right)-\min _{1 \leq i \leq m}\left(r_{i j}^{l e f}\right)} \\
v_{i j}^{r i g} & =\frac{r_{i j}^{r i g}-\min _{1 \leq i \leq m}\left(r_{i j}^{l e f}\right)}{\max _{1 \leq i \leq m}\left(v_{i j}^{r i g}\right)-\min _{1 \leq i \leq m}\left(r_{i j}^{l e f}\right)}
\end{aligned}
$$

The formula for the normalization of appropriatenessrelated measure indicator $j$ is $v_{i j}^{l e f}=$

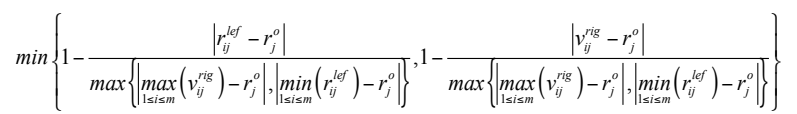

$$
\begin{aligned}
& v_{i j}^{r i g}=
\end{aligned}
$$

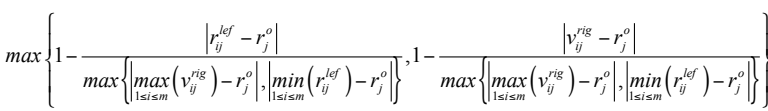

\section{Fuzzy analysis model for the measure indicators}

All measure indicators have uniform dimensionality after normalization. Let the normalized value of measure indicator $j$ for counselor $i$ be $v_{i j}=\left[v_{i j}^{l e f}, v_{i j}^{\text {rig }}\right]$, then the fuzzy ideal value $v_{o j}$ for indicator $j$ is calculated as

$$
v_{o j}=\left[v_{o j}^{l e f}, v_{o j}^{r i g}\right]=\left[\max _{1 \leq i \leq m}\left(v_{i j}^{l e f}\right), \max _{1 \leq i \leq m}\left(v_{i j}^{r i g}\right)\right]
$$

The fuzzy ideal sequence $V_{o}$ of measure indicators is formed as follows for the measure analysis scheme set:

$$
V_{o}=\left\{v_{o 1}, v_{o 2}, \mathrm{~L}, v_{o j}, \mathrm{~L}, v_{o n}\right\}
$$

$$
\text { The fuzzy distance } K_{i j} \text { between }
$$

the measure indicator $j$ and the fuzzy ideal value $v_{o j}$ for counselor $i$ is calculated as follows:

$$
K_{i j}=\sqrt[T]{\frac{\left|v_{o j}^{l e f}-v_{i j}^{l e f}\right|^{T}+\left|v_{o j}^{r i g}-v_{i j}^{r i g}\right|^{T}}{2}}
$$

Generally, $T=2$. Fuzzy distance $K_{i j}$ is the Euclidean distance, and the above formula becomes

$$
K_{i j}=\sqrt{\frac{\left|v_{o j}^{l e f}-v_{i j}^{l e f}\right|^{2}+\left|v_{o j}^{r i g}-v_{i j}^{r i g}\right|^{2}}{2}}
$$

With fuzzy distance $K_{i j}$ obtained, the maximum fuzzy distance $D I S_{\max }$ and the fuzzy distance $D I S_{\min }$ of performance measure indicator are calculated for the measure analysis scheme set with respect to the measure indicator set:

$$
\begin{aligned}
& D I S_{\max }=\max _{1 \leq i \leq m} \max _{1 \leq j \leq n}\left(K_{i j}\right) \\
& D I S_{\min }=\min _{1 \leq i \leq m} \min _{1 \leq j \leq n}\left(K_{i j}\right)
\end{aligned}
$$

Thus the gray relevance coefficient $\delta_{i j}$ between measure indicator $j$ and fuzzy ideal value $v_{o j}$ for counselor $i$ is expressed as

$$
\delta_{i j}=\frac{D I S_{\min }+\beta * D I S_{\max }}{\left|K_{i j}\right|+\beta * D I S_{\max }}
$$

Where $\rho$ is the distinguishing coefficient in gray relevance analysis, $\rho \in[0,1]$ and $\rho=0.5$.

Different measure indicators may have different weights. If the weight of measure indicator $j$ is $w_{j}$, the weighted gray relevance $\psi_{i}$ between the measure indica- 
tor and the fuzzy ideal sequence $V_{o}$ of the indicators is expressed as

$$
\psi_{i}=\sum_{j=1}^{n}\left(w_{j} * \delta_{i j}\right)
$$

According to the principle of selecting the best in decision-making analysis, there is

$$
\psi_{\max }=\max \left(\psi_{1}, \psi_{2}, \mathrm{~L}, \psi_{m}\right)=\psi_{t}
$$

Thus counselor $t$ has the best performance.

Similarly, let the threshold of the performance measure be $\psi_{0}$. If

$$
\psi_{t} \geq \psi_{0}
$$

Then counselor $t$ is qualified.

Further, the performance of counselor can be classified into different grades based on gray relevance $\psi_{t}$ using threshold $\psi_{0}$. For example, if the gray relevance $\psi_{t}$ falls into the interval corresponding to grade $S$, then this counselor is considered belonging to the grade $S$.

\section{CASE STUDY AND MODEL VERIFICATION}

The yearly performance evaluation data of counselors in charge of undergraduate class in a provincial-level key college are used to verify the proposed measure system. Combining the opinions of the leaders of the school and the experts, the raw data of performance measure analysis are obtained by scoring and statistical analysis (Table III).

Using the normalization formulae and the fuzzy distance formula proposed in this article, the fuzzy distance of different indicators for each counselor is calculated, as shown in Table IV.

The gray relevance coefficients are calculated for each measure indicator using the gray relevance model, with the results given in Table $\mathrm{V}$.

Thus the sequence of gray relevance for each counselor is obtained as $\psi=(0.6523,0.9234,0.6788,0.6394)$. It can be seen that counselor B has the best performance. If the threshold is set as 0.60 , then all counselors are qualified in this year. This is consistent with the actual performance evaluation result by the school.

\section{CONCLUSION}

This article proposes a college counselors' performance measure system, based on which the fuzzy measure model is established. After normalization of the measure indicators, the fuzzy distance model and the gray relevance model are constructed for counselors' performance evaluation. The performance of college counselors working at a specific university is then evaluated based on comprehensive gray relevance. The result shows that the model is reliable in performance evaluation of college counselors.

\begin{tabular}{|c|c|c|c|c|c|c|c|}
\hline \multirow{2}{*}{$\begin{array}{l}\text { Primary } \\
\text { indicator }\end{array}$} & \multirow{2}{*}{ Weight } & \multirow{2}{*}{$\begin{array}{c}\text { Secondary } \\
\text { indicator }\end{array}$} & \multirow{2}{*}{ Weight } & \multicolumn{4}{|c|}{ Counselor } \\
\hline & & & & A & B & $\mathrm{C}$ & D \\
\hline \multirow{5}{*}{$C_{1}$} & \multirow{5}{*}{0.15} & $c_{11}$ & 0.25 & $80-90$ & $90-100$ & $90-100$ & $80-90$ \\
\hline & & $c_{12}$ & 0.10 & $90-100$ & $90-100$ & $70-80$ & $70-80$ \\
\hline & & $c_{13}$ & 0.25 & $90-100$ & $80-85$ & $90-100$ & $80-85$ \\
\hline & & $c_{14}$ & 0.20 & $75-80$ & $90-100$ & $75-80$ & $80-85$ \\
\hline & & $c_{15}$ & 0.20 & $50-60$ & $90-100$ & $70-80$ & $50-60$ \\
\hline \multirow{6}{*}{$C_{2}$} & \multirow{6}{*}{0.10} & $c_{21}$ & 0.15 & $40-50$ & $90-100$ & $50-60$ & $50-60$ \\
\hline & & $c_{22}$ & 0.10 & $90-100$ & $90-100$ & $90-100$ & $\begin{array}{l}90- \\
100\end{array}$ \\
\hline & & $c_{23}$ & 0.15 & $80-90$ & $80-90$ & $90-100$ & $70-80$ \\
\hline & & $c_{24}$ & 0.25 & $80-90$ & $90-100$ & $50-60$ & $50-60$ \\
\hline & & $c_{25}$ & 0.20 & $50-60$ & $90-100$ & $80-90$ & $50-60$ \\
\hline & & $c_{26}$ & 0.20 & $80-90$ & $80-90$ & $90-100$ & $\begin{array}{c}90- \\
100 \\
\end{array}$ \\
\hline \multirow{8}{*}{$C_{3}$} & \multirow{8}{*}{0.25} & $c_{31}$ & 0.15 & $90-100$ & $70-80$ & $90-100$ & $70-80$ \\
\hline & & $c_{32}$ & 0.20 & $80-90$ & $90-100$ & $50-60$ & $\begin{array}{l}90- \\
100 \\
\end{array}$ \\
\hline & & $c_{33}$ & 0.15 & $80-90$ & $90-100$ & $90-100$ & $70-80$ \\
\hline & & $c_{34}$ & 0.10 & $80-90$ & $80-90$ & $90-100$ & $50-60$ \\
\hline & & $c_{35}$ & 0.10 & $70-80$ & $90-100$ & $70-80$ & $\begin{array}{c}90- \\
100 \\
\end{array}$ \\
\hline & & $c_{36}$ & 0.10 & $90-100$ & $70-80$ & $90-10$ & $50-60$ \\
\hline & & $c_{37}$ & 0.15 & $50-60$ & $90-100$ & $50-60$ & $80-90$ \\
\hline & & $c_{38}$ & 0.05 & $80-90$ & $90-100$ & $50-60$ & $\begin{array}{c}90- \\
100 \\
\end{array}$ \\
\hline \multirow{8}{*}{$C_{4}$} & \multirow{8}{*}{0.30} & $c_{41}$ & 0.10 & $80-90$ & $90-100$ & $90-100$ & $80-90$ \\
\hline & & $c_{42}$ & 0.10 & $80-90$ & $90-100$ & $80-90$ & $80-90$ \\
\hline & & $c_{43}$ & 0.10 & $80-90$ & $90-100$ & $80-90$ & $80-90$ \\
\hline & & $c_{44}$ & 0.15 & 0.85 & 1.00 & 0.80 & 0.85 \\
\hline & & $c_{45}$ & 0.10 & 0.60 & 1.00 & 0.40 & 0.60 \\
\hline & & $c_{46}$ & 0.10 & 0.60 & 1.00 & 0.40 & 0.60 \\
\hline & & $c_{47}$ & 0.15 & 0.05 & 0 & 0.05 & 0 \\
\hline & & $c_{48}$ & 0.20 & $80-90$ & $90-100$ & $80-90$ & $80-90$ \\
\hline \multirow{6}{*}{$C_{5}$} & \multirow{6}{*}{0.20} & $c_{51}$ & 0.15 & $80-90$ & $90-100$ & $70-80$ & $\begin{array}{l}90- \\
100\end{array}$ \\
\hline & & $c_{52}$ & 0.15 & $80-90$ & $90-100$ & $80-90$ & $\begin{array}{l}90- \\
100 \\
\end{array}$ \\
\hline & & $c_{53}$ & 0.15 & $70-80$ & $90-100$ & $50-60$ & $\begin{array}{c}90- \\
100 \\
\end{array}$ \\
\hline & & $c_{54}$ & 0.15 & $80-90$ & $70-80$ & $90-100$ & $\begin{array}{c}90- \\
100 \\
\end{array}$ \\
\hline & & $c_{55}$ & 0.25 & $90-100$ & $90-100$ & $80-90$ & $70-80$ \\
\hline & & $c_{56}$ & 0.15 & $80-90$ & $90-100$ & $70-80$ & $80-90$ \\
\hline
\end{tabular}

TABLE III.

RAW DATA OF PERFORMANCE MEASURE ANALYSIS 
PAPER

College Counselors’ Performance Measure System and Fuzzy Measure Analysis Model

TABLE IV.

FUZZY DISTANCE FOR EACH COUNSELOR

\begin{tabular}{|c|c|c|c|c|}
\hline \multirow{2}{*}{$\begin{array}{c}\text { Secondary indi- } \\
\text { cator }\end{array}$} & \multicolumn{4}{|c|}{ Counselor } \\
\hline & $\mathrm{A}$ & $\mathrm{B}$ & $\mathrm{C}$ & $\mathrm{D}$ \\
\hline$c_{11}$ & 0.100 & 0 & 0 & 0.100 \\
\hline$c_{12}$ & 0 & 0 & 0.200 & 0.200 \\
\hline$c_{13}$ & 0 & 0.127 & 0 & 0.127 \\
\hline$c_{14}$ & 0.177 & 0 & 0.177 & 0.127 \\
\hline$c_{15}$ & 0.400 & 0 & 0.200 & 0.400 \\
\hline$c_{21}$ & 0.500 & 0 & 0.400 & 0.400 \\
\hline$c_{22}$ & 0.100 & 0 & 0 & 0 \\
\hline$c_{23}$ & 0.100 & 0.100 & 0.100 & 0 \\
\hline$c_{24}$ & 0.100 & 0 & 0.400 & 0.400 \\
\hline$c_{25}$ & 0.400 & 0 & 0.100 & 0.400 \\
\hline$c_{26}$ & 0.100 & 0.100 & 0 & 0 \\
\hline$c_{31}$ & 0 & 0.200 & 0 & 0.200 \\
\hline$c_{32}$ & 0.100 & 0 & 0.400 & 0.100 \\
\hline$c_{33}$ & 0.100 & 0 & 0 & 0.200 \\
\hline$c_{34}$ & 0.100 & 0.100 & 0 & 0.400 \\
\hline$c_{35}$ & 0.200 & 0 & 0.200 & 0 \\
\hline$c_{36}$ & 0 & 0.200 & 0.200 & 0.400 \\
\hline$c_{37}$ & 0.400 & 0 & 0.400 & 0.100 \\
\hline$c_{38}$ & 0.100 & 0 & 0.400 & 0 \\
\hline$c_{41}$ & 0.100 & 0 & 0 & 0.100 \\
\hline$c_{42}$ & 0.100 & 0 & 0.100 & 0.100 \\
\hline$c_{43}$ & 0.100 & 0 & 0.100 & 0.100 \\
\hline$c_{44}$ & 0.15 & 0 & 0.20 & 0.15 \\
\hline$c_{45}$ & 0.40 & 0 & 0.60 & 0.40 \\
\hline$c_{46}$ & 0.40 & 0 & 0.60 & 0.40 \\
\hline$c_{47}$ & 0.05 & 0 & 0.05 & 0 \\
\hline$c_{48}$ & 0.100 & 0 & 0.100 & 0.100 \\
\hline$c_{51}$ & 0.100 & 0 & 0.200 & 0 \\
\hline$c_{52}$ & 0.100 & 0 & 0.100 & 0 \\
\hline$c_{53}$ & 0.200 & 0 & 0.400 & 0 \\
\hline$c_{54}$ & 0.100 & 0.200 & 0 & 0 \\
\hline$c_{55}$ & 0 & 0 & 0.100 & 0.200 \\
\hline$c_{56}$ & 0.100 & 0 & 0.200 & 0.100 \\
\hline
\end{tabular}

TABLE V.

GRAY RELEVANCE COEFFICIENTS FOR DIFFERENT COUNSELORS

\begin{tabular}{|c|c|c|c|c|}
\hline \multirow{2}{*}{$\begin{array}{l}\text { Secondary indi- } \\
\text { cator }\end{array}$} & \multicolumn{4}{|c|}{ Counselor } \\
\hline & $\mathrm{A}$ & $\mathrm{B}$ & $\mathrm{C}$ & $\mathrm{D}$ \\
\hline$c_{11}$ & 0.1668 & 0.250 & 0.250 & 0.1668 \\
\hline$c_{12}$ & 0.100 & 0.100 & 0.050 & 0.050 \\
\hline$c_{13}$ & 0.250 & 0.1543 & 0.250 & 0.1543 \\
\hline$c_{14}$ & 0.1062 & 0.200 & 0.1062 & 0.1234 \\
\hline$c_{15}$ & 0.0666 & 0.200 & 0.100 & 0.0666 \\
\hline$c_{21}$ & 0.0429 & 0.150 & 0.050 & 0.050 \\
\hline$c_{22}$ & 0.0667 & 0.100 & 0.100 & 0.100 \\
\hline$c_{23}$ & 0.100 & 0.100 & 0.1001 & 0.150 \\
\hline$c_{24}$ & 0.1668 & 0.250 & 0.0833 & 0.0833 \\
\hline$c_{25}$ & 0.0666 & 0.200 & 0.1234 & 0.0666 \\
\hline$c_{26}$ & 0.1234 & 0.1234 & 0.200 & 0.200 \\
\hline$c_{31}$ & 0.150 & 0.075 & 0.150 & 0.075 \\
\hline$c_{32}$ & 0.1234 & 0.200 & 0.0666 & 0.1234 \\
\hline$c_{33}$ & 0.1001 & 0.150 & 0.150 & 0.075 \\
\hline$c_{34}$ & 0.0667 & 0.0667 & 0.1000 & 0.0333 \\
\hline$c_{35}$ & 0.050 & 0.100 & 0.050 & 0.100 \\
\hline$c_{36}$ & 0.100 & 0.050 & 0.0500 & 0.0333 \\
\hline$c_{37}$ & 0.050 & 0.150 & 0.050 & 0.100 \\
\hline$c_{38}$ & 0.0334 & 0.050 & 0.1665 & 0.050 \\
\hline$c_{41}$ & 0.0667 & 0.100 & 0.100 & 0.0667 \\
\hline$c_{42}$ & 0.0667 & 0.100 & 0.0667 & 0.0667 \\
\hline$c_{43}$ & 0.0667 & 0.100 & 0.0667 & 0.0667 \\
\hline$c_{44}$ & 0.0857 & 0.150 & 0.075 & 0.0857 \\
\hline$c_{45}$ & 0.0333 & 0.100 & 0.0250 & 0.0333 \\
\hline$c_{46}$ & 0.0333 & 0.100 & 0.0250 & 0.0333 \\
\hline$c_{47}$ & 0.120 & 0.150 & 0.120 & 0.150 \\
\hline$c_{48}$ & 0.1234 & 0.200 & 0.1234 & 0.1234 \\
\hline$c_{51}$ & 0.1001 & 0.150 & 0.075 & 0.150 \\
\hline$c_{52}$ & 0.1001 & 0.150 & 0.1001 & 0.150 \\
\hline$c_{53}$ & 0.075 & 0.150 & 0.050 & 0.150 \\
\hline$c_{54}$ & 0.1001 & 0.075 & 0.150 & 0.150 \\
\hline$c_{55}$ & 0.250 & 0.250 & 0.1668 & 0.075 \\
\hline$c_{56}$ & 0.1001 & 0.150 & 0.075 & 0.1001 \\
\hline
\end{tabular}




\section{REFERENCES}

[1] Chen Guoqin. Several key points in performance evaluation of college counselors [J]. Ideological and Political Education Research, 2010, 26 (6): 110-112+118.

[2] Han Feng. Current situation and path of performance evaluation of college counselors [J]. Journal of Beijing Institute of Education, 2011, 25 (4): 21-24.

[3] Zhao Zudi, Liu Yun. Current strategies for performance evaluation of college counselors [J]. Heilongjiang Researches on Higher Education, 2013, 2: 80-82.

[4] Yu Ying, Xu Qicheng. Research on gray system evaluation model of comprehensive assessment of college counselors' work [J]. Science Mosaic, 2014, 5: 16-19.

[5] Deng Wenzhuo, Tong Hongzhi. Empirical analysis on college counselors' performance evaluation [J]. Economic Research Guide, 2011, 7: 282-284.

[6] Li Pinyu, Zhong Dingsheng. Study on grade-based performance evaluation index system and evaluation method for college counselors [J]. Journal of Higher Education Management, 2014, 8(2):98-103+116.

[7] Fang Hui. Counselors' performance evaluation of college A based on fuzzy comprehensive evaluation method [J]. Management Observer, 2009, 3; 85-87.

[8] Chen Yansong. Fuzzy comprehensive evaluation of college counselors' performance based on competence structure model [J]. Jiangsu Higher Education, 2011, 1:102-104.

[9] Huang Jingqiu, Liu Jun. Competence-based 360-degree performance evaluation of college counselors [J]. Communist Party Construction and Ideological Education of School, 2013, 5: 87$88+96$.

[10] R. Rajesh, V. Ravi. Supplier selection in resilient supply chains: a grey relational analysis approach [J]. Journal of Cleaner Production, 2015, 86(1): 343-359. http://dx.doi.org/10.1016/j.jclepro. 2014.08.054

[11] R. Vinayagamoorthy, M. Anthony Xavior. Parametric Optimization on Multi-Objective Precision Turning Using Grey Relational Analysis [J]. Procardia Engineering, 2014, 97: 299-307. http://dx.doi.org/10.1016/j.proeng.2014.12.253

[12] Tsai-Fu Chuang, Yuan-Hsiou Chang. Comparison of physical characteristics between Rana latouchtii and Rana adenopleura using grey system theory and Artificial Neural Network [J]. Ecolog- ical Engineering, 2014, 68 (7): 223-232. http://dx.doi.org/10.1016/ j.ecoleng.2014.03.038

[13] Hoseyn Sayyaadi, Meisam Babaie, Mohammad Reza Farmani. Implementing of the multi-objective particle swarm optimizer and fuzzy decision-maker in exergetic, exergoeconomic and environmental optimization of a benchmark cogeneration system $[\mathrm{J}]$. Energy, 2011, 36(8): 4777-4789. http://dx.doi.org/10.1016/j.energy. 2011.05 .012

[14] Maisa Mendonça Silva, Ana Paula Henriques de Gusmão, Thiago Poleto, Lúcio Camara e Silva, Ana Paula Cabral Seixas Costa. A multidimensional approach to information security risk management using FMEA and fuzzy theory [J]. International Journal of Information Management, 2014, 34 (6): 733-740. http://dx.doi.org/10.1016/j.ijinfomgt.2014.07.005

[15] Radko Mesiar, Andrea Stupňanová. Open problems from the 12th International Conference on Fuzzy Set Theory and Its Applications [J]. Fuzzy Sets and Systems, 2015, 261: 112-123 http://dx.doi.org/10.1016/j.fss.2014.07.012

\section{AUTHORS}

Xin Xia, female, was born in Oct. 1981. She obtained master of literature from Hebei University. She now works at Agricultural University of Hebei, No.2596, Lekai of south Street, Baoding, Hebei, China as a lecturer, responsible for management of students and studying in ideological and political education. (E-mail: 16394605@qq).

Guolei Zhang, male, was born in Feb 1978. He obtained a master degree of agronomy from Agricultural University of Hebei in July 2007, and now works at College of Information Science and Technology in Agricultural University of Hebei No.289, Lingyusi Street, Baoding, Hebei, China as the vice dean and vice professor, studying in application of novel science and theories in management of college students. (E-mail: 123866119@qq.com).

Submitted 07 November 2015. Published as resubmitted by the authors 05 December 2015. 